\title{
Competitive Relations in the Aftersales Market of Major Home Appliances in Serbia
}

\author{
Ivana Domazet $^{1 *}$ ～Ivan Stošić ${ }^{1}$ | Milena Lazić ${ }^{2}$ \\ ${ }^{1}$ Institute of Economic Sciences, Belgrade, Serbia \\ 2 Belgrade Banking Academy, Belgrade, Serbia
}

\begin{abstract}
The primary goal of this paper is to deepen the knowledge and provide analysis of the basic features of the major appliances aftersales market in the Republic of Serbia. This is relatively large, and for a huge number of consumers significant market, which, according to the available knowledge, was not the subject to more detailed research until now. Therefore, through a combination of survey (desk) and secondary (field) research, a detailed overview of the scope and structure of the major appliances aftermarket was carried out. With the aim to identify potential issues and propose curative to overcome them, an analysis on the competitive relations between the main actors and the factors that predominantly affect the market relations in this segment of the aftersales market was conducted. Bearing in mind the basic characteristics of the primary market in Serbia, it can be concluded that interbrand competition on the major appliances aftermarket is intense, and that significant issues are noticed. A potential problem related to competitive relations in this market segment is reflected in the constraints of intrabrand competition (competition between distributors / servicers / spare parts resellers of the same brand). The manufacturer is in a position to impose restrictions on distributors in respect of the terms of their contracts with authorized services and spare parts dealers, obliging them to install / sell spare parts exclusively from its production. Restrictions of this kind are justified only if they provide higher quality of the after-sales service. Otherwise they represent a serious distortion of competitive market behavior, as this limits the entry of independent spare parts manufacturers and servicers, who can offer spare parts and technical and repairing services of the appropriate quality.
\end{abstract}

Key words: aftermarket, major home appliances, household appliances, competition, Serbia

JEL Classification: L10, L68

\section{INTRODUCTION}

Aftermarkets or secondary markets can be defined as markets for complementary products (secondary products) which are usually purchased subsequent to the purchase of another, related product (primary product) (Carlton, 2010, Coppi, 2007). In other words, the term aftermarkets refers to markets for complementary goods and services such as maintenance, upgrades, and replacement parts used in conjunction with durable goods (Carlton \& Waldman, 2006, p. 1). According to some authors (Cohen, Agrawal \& Agrawal, 2006) in industries such as automobiles, white goods, industrial machinery, and information technology, companies have sold so many units over the years that their aftermarkets have become four to five times larger than the original equipment businesses.

\footnotetext{
${ }^{*}$ Senior Research Associate, Institute of Economic Sciences, Belgrade, Serbia, e-mail: ivana.domazet@ien.bg.ac.rs
} 
The aftermarket business, as a result of changed customers demand, increased competition and diminishing profit margins, has gained strategic importance for numerous industries over the past few decades. The reasons for this lay in the fact that aftermarket services stabilize company's long-term revenues, enhance customer satisfaction and offer an essential strategic weapon in a competitive environment. Therefore and due to increasing number of companies, aftermarkets are acknowledged as a rich source of revenue, profit and customer loyalty (Domazet \& Stošić, 2017).

The aftermarket business has certain characteristics:

- The basic parameters in the aftersales (secondary) market are largely determined by changes in the volume and structure of sales revenues in the relevant primary market

- The intensity of competitive relationships, as well as the sales margin on the aftermarket are largely determined by the position of the suppliers (sellers) in the primary market.

- A large number of suppliers (sellers) opt to operate in both the primary and secondary markets of a particular product category, thus creating significant barriers to the entry of new competitors.

When it comes to the situation in Serbia, the major appliances aftermarket is also a significant subsystem of the entire market, as indicated by the following data:

- According to the data of the Republic Institute for Statistics, 98.3\% of households in Serbia $(2,487,886)$ have a refrigerator, and $93.6 \%$ of households have a washing machine. In quantitative terms, this would mean that around 2.445 million refrigerators and 2.328 million washing machines is in use in Serbia.

Table 1. Comparative overview of the number of households in the period 1991-2011*, by region

\begin{tabular}{|l|r|r|r|}
\hline & \multicolumn{1}{|c|}{$\mathbf{1 9 9 1}$} & \multicolumn{1}{|c|}{$\mathbf{2 0 0 2}$} & \multicolumn{1}{|c|}{$\mathbf{2 0 1 1}$} \\
\hline Republic of Serbia & $2,418,156$ & $2,521,190$ & $2,487,886$ \\
\hline Serbia - North & $1,200,296$ & $1,277,282$ & $1,302,590$ \\
\hline Belgrade region & 515,040 & 567,325 & 606,433 \\
\hline Region of Vojvodina & 685,256 & 709,957 & 696,157 \\
\hline Serbia - south & $1,217,860$ & $1,243,908$ & $1,185,296$ \\
\hline Region of Šumadija and Western Serbia & 657,792 & 678,934 & 662,769 \\
\hline Region of South and East Serbia & 560,068 & 564,974 & 522,527 \\
\hline
\end{tabular}

Source: The Institute for Statistics of the Republic of Serbia; *Censuses 1991-2011 do not contain data on households in Autonomous Province of Kosovo and Metohija.

- According to the Ministry of Finance, the Customs Administration and the Republic Institute for Statistics, it was estimated that 151,812 new refrigerators and 171,472 new washing machines were sold in Serbia in 2017.

Table 2. Insight on the use of refrigerators in Serbia in 2017

\begin{tabular}{|c|c|c|}
\hline $\begin{array}{c}\text { Total number of } \\
\text { refrigerators }\end{array}$ & $\begin{array}{c}\text { Number of refrigerators } \\
\text { purchased in 2017 }\end{array}$ & $\begin{array}{c}\text { \% of new refrigerators in the } \\
\text { total number }\end{array}$ \\
\hline $2,527,590$ & 151,812 & $6.01 \%$ \\
\hline
\end{tabular}

Source: Ministry of Finance, Customs Administration, the Institute for Statistics of the Republic of Serbia 
Table 3. Insight on the use of washing machines in Serbia in 2017

\begin{tabular}{|c|c|c|}
\hline $\begin{array}{c}\text { Total number of } \\
\text { washing machines }\end{array}$ & $\begin{array}{c}\text { Number of washing machines } \\
\text { purchased in 2017 }\end{array}$ & $\begin{array}{c}\text { \% of new washing machines in } \\
\text { the total number }\end{array}$ \\
\hline $2,350,664$ & 171,472 & $7.30 \%$ \\
\hline
\end{tabular}

Source: Ministry of Finance, Customs Administration, the Institute for Statistics of the Republic of Serbia

Regardless of the size and significance, the major appliances aftermarket in Serbia was not the subject to more detailed analyzes and studies, which suggests that knowledge about the market in question is still very limited. From this point of view, the subject of this paper is the examination of the basic dimensions, structure, characteristics and current issues in the major appliances aftermarket in Serbia. The main goal of the research is identification of specific market structure, the behavior of market players, and the types of relations between them as well as the analysis of the factors affecting the after sales service and customer satisfaction.

The paper consists of four main chapters. After introductory considerations, the second chapter of the paper presents a review of the literature and the design of the research. The third chapter of the paper presents the results of the conducted research arranged into three parts Basic characteristics of the major appliances aftermarket in Serbia, Different perspectives of chosen key stakeholders and Basic characteristics of competitive relations in the major appliances aftermarket in Serbia. The fourth chapter summarizes the results of the research and provides recommendations for further research work in the area.

\section{LITERATURE REVIEW AND RESEARCH DESIGN}

It is widely accepted that the after sales services may be defined as the various processes with the main purpose to make sure customers are satisfied with the products and services of the organization. In other words, after sales services are important part of total customer satisfaction. The companies may ensure product functionality and customer satisfaction by offering different aftermarket services. In fact, aftermarket services can create sustainable relationships with customers and contribute significantly to their satisfaction (Kurata \& Nam, 2010), (Ahn \& Sohn, 2009).

According to certain authors (Slater, 1996), (Wilson, 1999) aftersales services represent a significant source of competitive advantage for the companies that operate in the same market. In support of the above, the authors Seth, Deshmukh and Vrat (Seth, Deshmukh \& Vrat, 2005) in their study point out that the after-sales activities are recognized as a primary source of revenue, profit and competitive advantage for many industries. The focus of prior research has been also the critical factor of a firm's success (Hakansson \& Snehota, 2006) particularly on spare parts supply, optimal warranty periods, components which should be included or excluded from a warranty, approaches to better utilize the benefits of the spare parts business, analysis of supply strategies, optimal final order quantities, etc. Numerous publications in the field of spare parts logistics and management focused their scope to one or a few of the constituent components of a spare parts logistics strategy (Aronis, Magou, Dekker \& Tagarsa, 2004), (Kumar, 2005).

Last, but not least, numerous researchers have concentrated on legal aspects of aftermarkets and their impact on competition restraint. In his paper Bauer (Bauer, 2007) defined the aftermarket restraints as the techniques by which a firm selling a product which is frequently referred to as the "primary product" is able to require its customers to purchase some other product or service-oftentimes referred to as the "secondary product"-from that firm. The 1992 "Kodak decision" by the US Supreme Court raised several questions about aftermarkets, and especially about the circumstances under which behavior by OEMs can have anticompetitive effects (Goldfine \& Vorrasi, 2004), (Hovenkamp, 1993). In the report of the Organization for Economic Co-operation and Development (Capobianco, Ogawa \& Abate, 2017) it is stated that 
from a competition perspective, the manufacturer of the primary good is often a major supplier in the aftermarket and may enjoy market power in the secondary market, which raises questions as to whether antitrust intervention is warranted to protect consumer welfare on the primary and secondary markets.

The report prepared for the needs of The European Committee of Domestic Equipment Manufacturers (The economic impact of the domestic appliances industry in Europe: Report for the European Committee of Domestic Equipment Manufacturers (CECED), 2015) presents the basic parameters of business operations in the major appliances sector of the EU Member States. According to the report, in the period from 2008 to 2012, there was a decline in sales revenues from 52 billion euros to 44 billion euros, followed by a slight increase in 2013, when sales revenues amounted to 48 billion euros. In addition, it is estimated that the number of employees in this sector decreased by about 20,000 in the period 2009-2011. When it comes to regulation of business operations in this sector, there is a need to increase energy efficiency as soon as possible. According to the author, despite the negative indicators of business in the post-World Economic Crisis period, the major appliances sector remains an important segment of the EU economy

However, there is a huge gap between the high importance of the aftermarket business for an increasing number of companies, and the scientific literature dealing with the aftermarkets and the strategic positioning of its players. The situation is similar when it comes to research in this area in Serbia. Nevertheless, in recent years, several studies have been conducted on this topic. The results of their research indicated that the proximity of technical and repair services for major appliances is, beside the price, one of the most important criteria for their choice (Domazet \& Simeunović, 2015).

In addition to the above mentioned, the study Aftermarkets (Comission for protection of competition, 2016) provides an analysis of the key dimensions and issues of the major appliances products and services aftermarket, primarily from the aspect of regulatory conventions in the competition protection segment.

Taking into account the object and purpose of the research, the research method used in this paper included the combination of desk, field and expert model.

Conducted desk research involved the collection and analysis of aggregate data relevant to the major appliances products and services aftermarket. The main sources of aggregate data and information used for this analysis are: Data of the Business Registers Agency on the number of participants in the market based on the registered main activity; Data from the Ministry of Finance - Customs Administration on import and export of relevant types of products (bestselling major appliances, spare parts); Data from the Ministry of Trade of the Republic of Serbia on the sale of household appliances and consumer complaints; Data from the Republic Institute for Statistics on production of goods, import and export of white goods; Data of Serbian Chamber of Commerce, Trade Association, Commission for Protection of Competition and publicly available data on the Internet.

Field research was carried out using the survey method through semi-structured questionnaires (with additional personal interviews in situations where it was possible) in the period from February 1 to May 31, 2018. A sample of 84 respondents consisted of relevant market participants belonging to different segments of major appliances aftermarket in Serbia. The basic criteria used to select the respondents for the sample were, first of all, the income, the number of employees, the significant representation in the import, wholesale and retail of spare parts of major appliances. In addition to the companies, business entities registered as entrepreneurial agencies engaged in servicing, and which are estimated to represent significant market participants, were included in the sample.

After completion of all interviews, the analysis was conducted followed by a cross-case analysis. The results of the conducted research were presented in the next chapter of the paper. 


\section{BASIC CHARACTERISTIC OF THE MAJOR HOME APPLIANCES AFTERMARKET IN SERBIA}

The characteristics of the key factors determining the size and structure of the major appliances aftersales market in the Republic of Serbia are the following:

- There is around 30 brands present in the major appliances market in the Republic of Serbia, and interbrand competition in the market of major appliances (washing machines and refrigerators) is high. According to the conducted research, the leader in the sale of refrigerators and washing machines is the brand Gorenje, with over 30\% of the market share, which has 37 authorized services. The brand Beko is following with approximately $13 \%$ of the market share and a network of 52 authorized services. The brand Vox holds around 10\% market share. Candy and Whirlpool brands have a market share of around $7-9 \%$, while the other 26 brands together have a $35-40 \%$ stake in selling new refrigerators and washing machines.

Table 4. Estimated market share of major appliances leading brands in the sale of refrigerators and washing machines in 2017. (sales volume)

\begin{tabular}{|l|c|}
\hline \multicolumn{1}{|c|}{ Brand name } & Market share in \% \\
\hline Gorenje & Over 30\% \\
\hline Beko & $10-13 \%$ \\
\hline Vox & $8-10 \%$ \\
\hline Candy & $7-9 \%$ \\
\hline Others & $35-45 \%$ \\
\hline
\end{tabular}

Source: Field research results, author's survey, publicly available websites of general representatives and major appliances central services

- The Herfindahl-Hirschman Index, the most important market concentration index used in competition law, calculated on the basis of physical sales volume of major appliances individual brands is 1.3641, which indicates that it is a market with moderate concentration. In the past period, in the washing machines and refrigerators market, only the brand Gorenje had a market share of more than $30 \%$ (Table 4.).

- The main trend in the white goods market in the past five to seven years showed a decline in demand, which is a consequence of the downtrend in the real financial power of the population. At that, orientation towards cheaper brands is evident. The only way for traders with technical goods to survive on the market at a time of unfavorable economic situation, are numerous special offers and discounts, deferred payments, the possibility of obtaining interest-free loans at the point of sale and other purchase incentives.

- The downward trend in business activity, impacts the major appliances aftersales services market, that is, the decrease in the number of employees and the realized business income of companies registered for performing activities under the code 9522 Repair of household appliances and home and garden equipment in the territory of the Republic of Serbia. According to the Business Registers Agency data, the total operating income of companies registered under the code 9522 in the period 2012-2014 decreased from 15.82 to 7.26 million euros, while the number of employees from 343 in 2012 decreased to 299 in 2017

- Given that the average lifetime of the refrigerator and washing machine is estimated at 10-12 years, and that the defect rate in the warranty period is 1.5-2\% (and after the

${ }^{1}$ Calculated based on the average of the estimated market share of brands 
warranty period increases incrementally every two years by about 2\%), the major appliances aftermarket (washing machines and refrigerators) is estimated at around 1315 million euros, of which 4-5\%, or 0.5-1 million euros appertains to the aftersales services market in the guarantee period.

Table 5. An assessment of the major appliances aftersales services market in 2017

\begin{tabular}{|l|c|}
\hline \multicolumn{1}{|c|}{ Market type } & In millions of euros \\
\hline New washing machines and refrigerators market & $70-75$ \\
\hline Major appliances aftermarket - total & $13-15$ \\
\hline Major appliances aftermarket - in the warranty period & $0,5-1$ \\
\hline
\end{tabular}

Source: Author's estimate based on the research

By conducting field research, which included interviews with experts in the field of servicing and the length of the warranty period of major appliances, we conclude that the average number of defects on new refrigerators and washing machines at the annual level is around $1.5-2 \%$. Compared to the number of new refrigerators and washing machines sold, on the annual level, the average percentage of refrigerator defects is $1.77 \%$, while washing machines partake $1.95 \%$.

The percentage of defects in relation to the quantity of washing machines and refrigerators sold in 2017 is $1.5-2 \%$ depending on the manufacturer, which is a relatively small percentage, but determines the aftersales services market in the warranty period. Since the spare parts for the repair of washing machines and refrigerators during the warranty period are not charged, and the authorized servicers of the leading brand (Gorenje) do not charge the service (replacing the part within the warranty period) either, major appliances aftermarket in the Republic of Serbia is estimated at 0.5-0.75 million euros. The total post-sales service market in the warranty period is estimated at 12-15 million euros.

- Authorized services of major appliances perform repairs both in and out the warranty period. The terms of the service vary, because the warranty period provides the buyer with a free replacement of the defective part with the original, and for certain brands, authorized services provide a complete repair (replacement of the spare part with the work of the service technician, as well as the potential transport of the product if the major repair is possible only in the service and not at the customer's location) in the warranty period for free. Certain number of authorized services that charge a repair service within the warranty period (with all authorized services, spare parts are free of charge within the warranty period) have an official pricelist of small and large repair services and it is precisely defined in which category each service work belongs.

Table 6. Number of authorized and independent major appliances services

\begin{tabular}{|c|c|c|}
\hline $\begin{array}{c}\text { Authorized major appliances } \\
\text { services }\end{array}$ & $\begin{array}{c}\text { Independent major appliances } \\
\text { services }\end{array}$ & Total \\
\hline 540 & $810-1,000$ & $1,350-1,500$ \\
\hline
\end{tabular}

Source: Author's estimate based on the Business Registers Agency data and publicly available data of the major appliances central authorized services

\section{Different perspectives of chosen key stakeholders}

An analysis of the economic aspects of establishing a network of authorized services from the perspective of the manufacturer / importer or the angle of the consumer of major appliances can be summarized as follows: 
Manufacturer / importer or representative perspective:

- According to Business Registers Agency data, as well as publicly available data from general distributors, authorized and independent services on the major appliances market, the relevant entities in the major appliances aftermarket are: 24 general agents / distributors of household appliances, 540 authorized services, and an estimated number from about 810-1,000 independent white ware repairers. In addition, the relevant entities in the aftersales services market are also spare parts dealers for white goods. In addition to the major appliances leading brands central authorized services (Gorenje Studio d.o.o, LTH servis d.o.o, ERG d.o.o, Beotronik d.o.o. etc.), the most important traders dealing with spare parts sales in the major appliances market are: Loren d.o.o, Dekom d.o.o, Eurofrigo d.o.o, ELpok d.o.o, Tecnoricambi d.o.o, ASWO d.o.o.

- Manufacturers and importers (representatives and agents) of major appliances were faced with a sharp decline in white goods sales of around 35-40\%, especially after the economic crisis in the period 2009-2010. In that period, some of the leading major appliances distributors (retailers such as Tehnomarket, Techno Max, Eltim) stopped working. This was followed by a large rearrangement of forces in the major appliances market, and today, by market share, leading market entities in the white ware trade are: Roaming Electronics d.o.o. (retail shops known as „Tehnomanija“), Moskomerc Beograd (retail shops known as „SVT“) and Gorenje Studio d.o.o.

- Aftersales services represent a legal obligation, so general representatives and distributors invest significant efforts to organize their own network of authorized services and spare parts dealers.

- The dimensioning and territorial structuring of the network of the official major appliances services (usually dealers of original spare parts) is usually carried out by importers (general agents or distributors) in cooperation with manufacturers based on the territorial dispersion of defect reports through unified contact centers.

- The duration of the warranty period and the geographical coverage of the service network, besides the price of the new product, represent the most important marketing mix instruments and dominantly temper the customers for the purchase of a particular major appliance brand. These factors also direct the creation of sales strategies for importers and dealers in terms of giving longer warranty periods (leading brands of household appliances Gorenje, Beko, Vox, Candy give five year warranties on refrigerators and washing machines) and the expansion of service networks of their brands.

Authorized service / official dealer perspective:

- The status of an authorized service ensures greater security in the performance of activities and the purchase of spare parts under more favorable conditions (rebates and bonuses);

- In order to provide the status of an authorized service / official spare parts dealer, a series of pre-conditions must be fulfilled: obligation to do business according to the manufacturer's standards (e.g. obligation in terms of size and arrangement of business premises, disposal of appropriate equipment, tools and diagnostic devices, obligation to hold spare parts stock, obligation to install "original spare parts"). These obligations result in a better service for consumers, but also, according to conducted surveys, higher prices of aftersales services.

- In the major appliances aftermarket, there is moderate competition within the warranty period and very intensive price competition outside the warranty period between authorized and independent services. High price competition is a characteristic of the spare parts trade, especially in the segment of "non-original" replacement parts. 
- Authorized services point out that the biggest problem in the business is the disloyal competition of independent services operating in the "gray" zone and offering cheap and low quality spare parts (which no one controls). ${ }^{2}$

\section{Consumer perspective:}

- Major appliances consumers are interested in getting the best quality service at the lowest possible price. In this regard, apart from the price of a new product, the most important factor when purchasing a particular brand is the length of the warranty period and the proximity of the authorized service.

- Consumers do not recognize the issue of the major appliances price difference in and out the warranty period, nor complain about the differences in the quality of service of authorized and independent services. There was 755 customer complaints and claims in respect to major appliances in 2015, as registered by the Ministry of Trade of the Republic of Serbia. By product group, the highest number of complaints $40.7 \%$ was related to washing machines, and $24.6 \%$ to refrigerators. Most complaints refer to the need for advice regarding a particular defect in the purchased product.

- Consumers do not notice a structural distortion of competition in this market segment, either within or beyond the warranty period, as the Ministry of Trade recorded less than $0.4 \%$ of complaints concerning customer reclamations related to the difference in the repair price within and outside the warranty period, as well as complaints in respect to different treatment of repairs in or out of the major appliances warranty period.

\section{Basic characteristics of competitive relations in the major appliances aftermarket in Serbia}

According to the conducted analysis of the aggregate data and the results of the field research, there are around 1500 major appliances services in Serbia, of which 497 are authorized, and about 1000 are independent services. The dominant number of authorized white ware services are registered as entrepreneurs, while 88 of them are registered as legal entities for performing activities under the code 9522 - Repair of household appliances and home and garden equipment in the territory of the Republic of Serbia. Certain number of independent services are registered as entrepreneurs, while the dominant part (about 80\%) of major appliances independent services occasionally or temporarily perform this activity "in the black market".

The network of the official major appliances services is created by general agent or distributor, and it is usually centralized, with one (main) authorized service. The dispersion of service network mainly depends on the estimated number of defect reports, and the optimal geographical coverage with authorized services.

Most manufacturers, or general distributors of the leading brands of household appliances in the territory of the Republic of Serbia, have a centralized network of services, where there is a central service that incorporates a contact center with operaters who handle inbound calls (complaints and defect reports) of product buyers, that are equipped with a module for analizing the number and type of defect, and geographical location of complaints and defect reports. This is the basic input for designing the dimensions and geographical distribution of the authorized services network.

Central authorized services, besides servicing activity, handle the sale of original spare parts and customer inquiries, and provide technical instructions related to a particular product model. Central authorized services for major appliances, receive complaints and defect reports through contact centers and forward customer requests to one of their authorized services, according to the criterion of geographical proximity to the customer. Apart from designing the size of a network of authorized services in the territory of the Republic of Serbia, the analysis of the

\footnotetext{
${ }^{2}$ Source: Author's survey
} 
customer call registered in the contact center also enables better coordination and more effective management of spare parts stock. Namely, based on the call history data, the necessary spare parts for certain products can be predicted (for example, over $80 \%$ of the total call volume in the territory of the Republic of Serbia regarding the boiler defects, comes from the territory of the municipality of Jagodina, due to the specific water structure), which helps servicers from that areas to always have the necessary spare parts available, and perform repairs in a relatively short period of time.

There is no interbrand competition between authorized representatives within the warranty period, since they are obligated to use only original parts of their brands for spare parts replacement, when servicing and repairing of major appliances. Intrabrand competition between authorized services within the warranty period is moderate, which means that they are prioritized when receiving service requests from the centralized contact center of the general agent, according to the proximity of the geographical location of the customer who reported the defect. The location, or proximity of the authorized service, is the first criterion according to which the call for major appliance repair is distributed from the contact center, while the second criterion is the number, i.e. availability of the authorized service technician at the moment of service request.

As for independent white ware services (there is around 1000 of such companies in the territory of the Republic of Serbia), who perform their activities outside the warranty period, the competition is very intense and the market dictates service conditions and prices.

The results of the conducted survey indicate the following:

- The key problem encountered by household appliances servicers is unfair competition, or the presence of a large number of unregistered services that operate "in the black market".

- $80 \%$ of respondents believe that there is moderate competition among major appliances servicers, while the remaining $20 \%$ consider the intensity of competition in the market at an extremely high level.

- All surveyed service providers believe that the level of service prices on the market is low, while $80 \%$ believe that the main reason for this is the low purchasing power of end users, and unfair competition (60\%).

- In 2015, the revenue of authorized services on average accounted for about $55 \%$ of the total turnover in the white goods market in Serbia, while it is estimated that the revenues of independent service providers accounted for about $45 \%$.

- In the structure of revenues of authorized services realized in 2015, the servicing of products in the warranty period takes about $63 \%$, while the share of sales of white goods products outside the warranty period is slightly lower and on average it amounts for about $37 \%$.

- Authorized services use only original spare parts during servicing, which greatly affects the level of operating costs and, consequently, on the margin decrease.

- There are no barriers to the provision of technical information for the products considered as the major appliances. Original spare parts can be obtained from general distributors (Gorenje d.o.o, LTH servis d.o.o, ERG d.o.o, Beotronik d.o.o. and others), authorized service or retailers dealing with the sale of spare parts for major appliances (Loren d.o.o., Dekom d.o.o, ELpok d.o.o, Tecnoricambi d.o.o. and others). The availability of non-original spare parts is high through numerous retailers that, among other things, are engaged in the trade of spare parts for white goods.

- Entry barriers related to the provision of technical information related to the purchase of original spare parts were not recorded in the conducted surveys. Central authorized services even try to expand a network of retailers that will place genuine spare parts for 
home appliances because their standpoint is that this will lead to reducing the number of defect reports on major appliances of their brand. Central authorized services are obliged to provide customers with appropriate technical and service documentation and spare parts catalogs

- Small individual services, in particular those who are not registered and who operate in "grey zone" and "the black market", are not equipped with the appropriate technical equipment for using technical information or the purchase of original spare parts, and rely mainly on their experience and contacts with local stores of major appliances spare parts.

- Consumer Protection Act prescribes the right for major appliances customers for a warranty period of minimum 2 years. Leading brands of household appliances (Gorenje, Beko, Vox, Candy) give five-year warranty on refrigerators and washing machines ${ }^{3}$.

- The warranty includes the obligation of the guarantor or the authorized distributor or authorized retailer to eliminate all defects caused by the manufacturer's error without compensation. Services, that is, works and consumables (spare parts) covered by the guarantee are not charged to the buyer. The warranty covers repair of identified defects or, replacement of defected part(s), according to the assessment of the authorized service. The obligation to replace the parts that can be repaired is excluded. The guarantee implies that repairs and parts replacement can only be carried out by authorized service personnel. The warranty is void if repairs are carried out by unauthorized service, regardless of the scope of the repairs performed or if it is outside the service network.

The analysis of official price lists of white ware repairs used by authorized services that were submitted to the authors during the field survey, shows that the price of an authorized service technician's work hours is on average about 30\% higher compared to the price of the work hours of independent servicers.

Servicers in the warranty period justify differences of labor prices in the need for significantly higher investments in standards required by manufacturers (facilities, tools, training, information systems), as well as the fact that many servicers who service the product after the expiration of the warranty period operate in "gray" or "black" zones (i.e., only partially or completely fail to record parts and employees, do not provide fiscal accounts and do not pay legally prescribed taxes and contributions).

In addition, the analysis of responses from survey questionnaires and submitted price lists showed that prices of original spare parts are on average about $75 \%$ higher than the prices of replacement spare parts whose technical characteristics meet the quality but are not original spare parts. The stated price difference is the consequence of the poor quality of replacement parts, but also due to their shorter durability.

\section{CONCLUSIONS}

On the basis of the conducted research and analysis, it can be concluded that the major appliances aftersales service market is in many ways different from the "classic" product or some other type of services market, for several reasons:

\footnotetext{
${ }^{3}$ Five-year warranties were recorded during the period of realization of this research, and they can be related to a certain period of time of promotional campaigns or the consequence of conforming with current trands in the industry. The length of the warranty period is variable and amounts to a minimum of 2 years, which is stipulated by the Consumer Protection Act, and within the context of certain strategies and marketing campaigns, the warranty period can be extended.
} 
- The aftersales service market is largely defined by the primary market (e.g. the change in the volume and structure of sales of major appliances significantly defines trends in the relevant secondary, aftermarket for these products);

- The position of the suppliers in the primary market greatly influences the intensity of competitive relations and, consequently, the level of product prices and other competition parameters on the market of aftersales services. Nevertheless, there is a possibility that suppliers who do not have a dominant position in the primary market and operate at different levels of a production and sales chain, through some non-price or price factors, significantly affect the intensity of competition in the aftermarket, by applying different marketing strategies aimed at linking the primary product buyers to the aftersales services provided by the manufacturer of a particular brand, its distributors, or service providers;

- Many bidders operate simultaneously both in the primary and secondary markets, achieving a significantly higher level of profit in secondary market operations and creating barriers to entry of competitors or directing them exclusively to the primary or secondary market.

The refrigerators and washing machines aftermarket, as the best-selling major appliances products, is characterized by an extremely large number of subjects on the demand side (final product buyers), but also a relatively large number on the supply side of major appliances repair services (about 1,510 service technicians).

As a rule, the dimensioning and territorial structuring of the network of official major appliances services (usually dealers of genuine spare parts) is done by importers (general agents or distributors) in cooperation with manufacturers based on the territorial dispersion of defect reports through unified contact centers.

The duration of the warranty period and the geographical coverage of the service network represent, besides the price of the new product, the most important marketing mix instruments and dominantly define the customers for the purchase of a particular major appliances brand. These factors also direct the creation of sales strategies of importers and agents in terms of providing longer warranty periods and expanding service networks of their brands.

Authorized services conduct repairs within and out of the warranty period, while independent major appliances servicers are dominantly performing repairs out of the warranty period.

There is no Interbrand competition between authorized repairers within the warranty period, as authorized services are under contractual obligation to use exclusively the original parts of the brand for the reported major appliances repairs.

Intrabrand competition between authorized services within the warranty period is moderate, which means that they are prioritized when receiving service requests from the centralized contact center of the general agent, according to the proximity of the geographical location of the customer who reported the defect. The location, or proximity of the authorized service, is the first criterion according to which the call for major appliance repair is distributed from the contact center, while the second criterion is the number, i.e. availability of the authorized service technician at the moment of service request.

When speaking about independent major appliances services, there is around 1000 of such companies in the territory of the Republic of Serbia who perform their activities outside the warranty period. Here, the competition is very intense and the market dictates service conditions and prices

In the major appliances aftermarket, none of the 1,500 services has a market share of over $5 \%$, and we can conclude that it is a competitive market, that is, a market with an extremely low concentration. 
Problems in the field of competitive relations in the aftersales service market arise when interbrand competition (competition between manufacturers of different brands and their distributors) is not strong enough, or if the manufacturer of a particular brand has significant market share compared with the manufacturers of competing brands. In such a case, the manufacturer of certain brands and its distributors is not sufficiently stimulated to provide endcustomers with quality service for the repairing and installation of spare parts, despite the fact that they charge a high price for the basic product. Bearing in mind the basic characteristics of the primary market in Serbia, it can be noted that in the major appliances aftermarket, the interbrand competition is intense and that no significant problems are noticed.

Potential problems in the field of competitive relations in this market segment reflects in limitations of intrabrand competition (competition between distributors / services / spare parts resellers of the same brand). The manufacturer is in a position to impose restrictions on distributors in respect of the terms of their contracts with authorized services and spare parts dealers, obliging them to install / sell spare parts exclusively from its production. Restrictions of this kind are justified only if they provide higher quality of the after-sales service. Otherwise they represent a serious distortion of competitive market behavior, as this limits the entry of independent spare parts manufacturers and servicers, who can offer spare parts and technical and repairing services of the appropriate quality.

\section{ACKNOWLEDGEMENTS}

This paper is a result of the research project under the code 179015 (Challenges and Prospects of Structural Changes in Serbia: Strategic Directions for Economic Development and Harmonization with EU Requirements), and project European Integrations and Social and Economic Changes in Serbian Economy on the Way to the EU (code number 47009) financed by the Ministry of Education, Science, and Technological Development of the Republic of Serbia.

\section{REFERENCES}

Ahn, Jin Sook, and Sohn, So Young. 2009. "Customer pattern search for after-sales service in manufacturing". Expert Systems with Applications, 36 (3): 5371-5375.

Albek, Svend. 2013. "Consumer welfare in EU competition policy". European Comission.

Aronis, Kostas-Platon; Magou, Ioulia; Dekker, Rommert; Tagarasa, George. 2004. "Inventory control of spare parts using a Bayesian approach: A case study". European Journal of Operational Research, 154 (3): 730-739.

Bauer, Joseph P. 2007. "Antitrust implications of aftermarkets". Antitrust Bulletin, 52 (1): 31-51.

Bork, Robert H. 1993. "The antitrust policy: A policy war with itself, with a new introduction and epilogue". New York: Free Press.

Capobianco, Antonio, Ogawa, Satoshi, and Abate, Carolina. 2017. "Competittion issues in aftermarkets - Background note by the Secretariat". OECD - Directorate for financial and enterprise affairs, Competition Commeette.

Carlton, Dennis W. and Waldman, Michael. 2006. "Competition, monopoly and aftermarkets". Chicago: Johnson School Research Paper Series, 10-06.

Carlton, Denis W. 2010. "A general analysis of exclusionary conduct and refusal to deal: Why Aspen and Kodak are misguided". Cambridge: NBER Working paper No. 8105.

Cohen, Morris A., Agrawal, Narendra, and Agrawal, Vipul. 2006. "Winning in the aftermarket". https://hbr.org/2006/05/winning-in-the-aftermarket.

Coppi, Lorenzo. 2007. "Aftermarket monopolization: The emerging consensus in economics". Antitrust Bulletin, 52 (1): 53-72.

Domazet, Ivana, and Jovanović, Olivera. 2016. "Očuvanje životne sredine i tehnogeni izvori zagađenja". Ecologica, 23 (83): 529-533. 
Domazet, Ivana, and Simeunović, Ivana. 2015. "Company's fiduciary responsibility for the automobile liability insurance". Ekonomika preduzeća, 63 (3/4): 196-204.

Domazet, Ivana, and Stošić, Ivan. 2017. "Basic Characteristics of Competitive Relations in the After-Sales Market of Motor Vehicles in Serbia". Ekonomika preduzeća, 65(5/6): 413-426.

Domazet, Ivana, and Stošić, Ivan. 2013. "Strengthening the competitiveness of Serbian economy and the corporate market restructuring". Economyc Analysis, 46 (3/4)): 108-124.

Domazet, Ivana, Stošić, Ivan, Marković-Bajalović, Dijana, Hasan, Hanić, Simović, Vladimir, and Lazić, Milena. 2016. Istraživanje tržišta postprodajnih usluga (Aftermarkets), Institut ekonomskih nauka: 1-245.

Goldfine, David A.J., and Vorrasi, Kenneth M. 2004. "The fall of Kodak aftermarket doctrine: Dying a slow death". Antitrust Law Journal, 1/2004: 209-231.

Håkansson, Håkan; Snehota, Ivan. 2006. "No business is an island: The network concept of business strategy". Scandinavian Journal of Management, 22 (3): 256-270.

Hovenkamp, Herbert. 1993. "Market Power in Aftermarkets: Antitrust Policy and the Kodak Case". UCLA Law Review, 40 (6): 1447-1459.

Kumar, Sameer. 2005. "Parts management models and applications - A supply chain system integration perspective". New York: Springer.

Kurata, Hisashi, and Nam, Seong-Hyun. 2010. "After-sales service competition in a supply chain: Optimization of customer satisfaction level or profit or both?". International Journal of Produstion Economics, 127 (1):136-146.

Morita, Hodaka, and Waldman, Michael. 2010. "Competition, monopoly maintenance, and consumer switching costs". American Economic Journal: Microeconomics, 2 (1): 230-255.

Seth, Nitin; Deshmukh, S. G.; Vrat, Prem. 2005. "Service quality models: a review". International Journal of Quality \& Reliability Management, 22(9): 913-949.

Slater, Stanley F. 1996. "The challenge of sustaining competitive advantage". Industrial Marketing Management, 25(1): 79-86.

Stošić, Ivan and Domazet, Ivana. 2014. "Analiza konkurentnosti poslovanja i potencijali rasta privrede Srbije u periodu svetske krize”. Teme, 38 (2): 491-506.

Paraušić, Vesna, Domazet, Ivana, and Simeunović, Ivana. 2017. "Analysis of the Relationship Between the Stage of Economic Development and the State of Cluster Development". Argumenta Oeconomica, 39 (2): 279-305.

Europe Economics. 2015. "The economic impact of the domestic appliances industry in Europe: Report for the European Committee of Domestic Equipment Manufacturers (CECED)". http://www.europe-

economics.com/publications/the_economic_impact_of_the_domestic_appliances_industry_in_e urope_finaol_report.pdf.

Wilson, Timothy. 1999. "International After-Sales Services". Journal of Global Marketing, 5-27.

Vuković, Vlastimir, and Domazet, Ivana. 2013. "Problematični krediti i sistemski rizik: komparativna analiza Srbije i tranzicionih zemalja". Industrija 41 (4):59-74.

\begin{tabular}{|l|l|}
\hline Article history: & Received: May 20, 2018 \\
\cline { 2 - 2 } & Accepted: June 11, 2018 \\
\hline
\end{tabular}

